\title{
Does tree seedling growth and survival require weeding of Himalayan balsam (Impatiens glandulifera)?
}

\author{
Christian Ammer • Peter Schall • René Wördehoff • \\ Klaus Lamatsch • Martin Bachmann
}

Received: 30 June 2009/Revised: 3 March 2010/Accepted: 2 June 2010/Published online: 22 July 2010

(C) The Author(s) 2010. This article is published with open access at Springerlink.com

\begin{abstract}
The effect of Himalayan balsam (Impatiens glandulifera) on survival and growth of naturally regenerated silver birch (Betula pendula) and planted Norway spruce (Picea abies) and silver fir (Abies alba) seedlings was studied in a weeding experiment over 3 years. Three different treatments were applied: control, mowing, and hand weeding by pulling out the entire plant. There were no consistent treatment effects on height and diameter of the tree seedlings. The coverage of Rubus fruticosus had a negative impact on diameter increment of Norway spruce and silver fir. As opposed to growth, treatment effects on seedling survival could be found for planted Norway spruce and silver fir. However, it is very likely that these effects, namely higher seedling survival after mowing, have to be attributed to the control of bramble (Rubus fruticosus) rather than to that of Himalayan balsam. It is concluded that Himalayan balsam is not able to seriously affect the growth of already established seedlings.
\end{abstract}

\section{Keywords Impatiens glandulifera .}

Tree seedling growth · Competition · Weeding

This article originates from the final conference of the Cost action E47 "European Network for Forest Vegetation Management: Towards Environmental Sustainability" in Vejle, Denmark, 4-7 May 2009.

Communicated by Rainer Matyssek

C. Ammer $(\varangle)$ P P. Schall · R. Wördehoff

Department of Silviculture and Forest Ecology of the Temperate

Zones, Georg-August University Göttingen, Büsgenweg 1,

37077 Göttingen, Germany

e-mail: christian.ammer@forst.uni-goettingen.de

K. Lamatsch · M. Bachmann

Bavarian Forst Institute (LWF), Hans-Carl-von-Carlowitz-Platz 1, 85354 Freising, Germany

\section{Introduction}

Himalayan balsam is a summer-annual, half-shaded therophyte which is native in the Western Himalaya (from Kashmir to Nepal) at altitudes from 1,800 to 3,000 m above sea level (Hartmann et al. 1995; Grime et al. 2007). It was introduced to gardens as an ornamental in both Europe and North America in the early nineteenth century where it soon became invasive across large proportions of the two continents (Grime et al. 1988; Beerling and Perrins 1993; Toney et al. 1998). Since Himalayan balsam is clearly an invasive species and obviously forms dense thickets, it is also supposed to be a strong competitor to other species (Beerling and Perrins 1993; Pyšek and Prach 1995; Kowarik 2003). Based on the definitions given by Richardson et al. (2000), it is an invasive species. In fact, DAISIE (Delivering Alien Invasive Species Inventories for Europe) of the European Commission rates Himalayan balsam as one of the 100 worst alien species in Europe (www.europe-aliens.org).

In its native area of distribution, Himalayan balsam grows on riparian sites and in deciduous or mixed forests up to the timberline, preferring open or only slightly shaded sites (Hartmann et al. 1995; Pyšek and Prach 1995). In Europe, it prefers riparian habitats as well, but can also be found under open canopies on marshlands and around gaps in woodlands (Beerling and Perrins 1993). It prefers humid to wet, nutrient-rich, acidic to alkaline soils with high ground water or stands with a high air humidity (Ludwig et al. 2000) and is known to be very attractive for insects (Dierschke 2008). There are several reasons why Himalayan balsam has found its way into various sites (Koenies and Glavac 1979; Kowarik 2003). First of all, it is competitive on a wide range of soils with $\mathrm{pH}$ values ranging from 5.0 to 8.0 (Hartmann et al. 1995; Grime et al. 2007). Second, it is able to even grow and outcompete other 
species on sites which already have a well-established vegetation cover. Thus, it is able to outcompete field layer species even not only under high irradiance and increased $N$ supply but also in the shade and at low levels of $N$ (Andrews et al. 2009). Finally, it produces a high number of seeds and the seedlings additionally grow rapidly. Some authors therefore indicate Himalayan balsam as species which may already be associated with the potential natural vegetation, i.e., the hypothetical vegetation at a given site under the present environmental conditions, in some parts of Europe (Lohmeyer and Sukopp 1992). So far, it is the tallest annual plant in Europe (Beerling and Perrins 1993).

Prowse and Goodridge (2003) found a close relationship between the density of flowering individuals and the number of seedlings surviving until mid-May. They conclude that the period from mid-April to mid-May is important for a successful invasion in woodlands. Himalayan balsam blooms from July to October; seeds are released between August and October. They are ejected explosively up to 3-5 m. Long-distance spread is a consequence of human activities, e.g., sowing apiarists, grit transport on trucks, and water dispersal (Hartmann et al. 1995). The seeds can survive more than 1 year. Frost kills the plants, and this may limit the geographic distribution of Himalayan balsam (Pyšek and Prach 1995). Aside frost, drought affects the species and also reduces its competiveness (Lohmeyer and Sukopp 1992).

There are two major concerns about the invasion of Himalayan balsam. First, the bastardisation of flora, which might cause problems related to nature conservation. Second, that this neophyte might have detrimental effects on the establishment of tree seedlings and their growth. The second concern is dealt with in the study presented here. As Himalayan balsam is thought to be a strong competitor (Manchester and Bullock 2000), some techniques like mechanical weed control and the use of herbicides have been discussed (Beerling and Perrins 1993). So far, biological control agents are not available (Burkhart and Nentwig 2008). Burkhart and Nentwig (2008) have tested native antagonists and state that there was no impact of native antagonists on the performance of Himalayan balsam. Furthermore, they assume that only specialized herbivores and pathogens from the area of origin would be effective agents. Because the use of herbicides in forests is proscribed in Germany (Ammer et al. 2009), only mechanical treatments have been applied in former investigations. Hartmann et al. (1995) showed that the success of this treatment strongly depends on the date of intervention. Thus, weeding should be done as late as possible, i.e., between flowering and fructification, and as thoroughly as possible (Hartmann et al. 1995).

We do not know of any competition studies on the impact of Himalayan balsam on the performance of tree regeneration. Against this background, we addressed the following hypotheses: (1) Himalayan balsam restricts the survival and growth of tree seedlings and saplings and (2) mechanical weed control of Himalayan balsam increases survival and growth of forest regeneration.

\section{Materials and methods}

In fall 2005, two experiments were established in Southern Bavaria. The sites are located close to Irschenberg (47.848417 N, $11.906547 \mathrm{E} ; 725 \mathrm{~m}$ a.s.l.) and Wasserburg $(48.041564 \mathrm{~N}, 12.144822 \mathrm{E} ; 487 \mathrm{~m}$ a.s.l.). The mean annual temperature in Irschenberg is $7.4^{\circ} \mathrm{C}$, the total annual precipitation is $1,289 \mathrm{~mm} / \mathrm{a}$, the annual precipitation in the growing season is $880 \mathrm{~mm} / \mathrm{a}$, and the mean temperature in July is $16.7^{\circ} \mathrm{C}$ and in January $-1.3^{\circ} \mathrm{C}$. The corresponding values for Wasserburg are $8.4^{\circ} \mathrm{C}, 986 \mathrm{~mm} / \mathrm{a}, 703 \mathrm{~mm} / \mathrm{a}$, $17.6^{\circ} \mathrm{C}$ and $-1.1^{\circ} \mathrm{C}$. The length of the growing season, defined as number of days with a mean temperature above $5^{\circ} \mathrm{C}$, is 218 days for Irschenberg and 228 days for Wasserburg. At Irschenberg, the soils are characterized by moderate fresh to fresh silt and at Wasserburg by moderate fresh to fresh, rocky, sandy silt. The stands at the two sites had been dominated by mature Norway spruce (Picea abies (L.) Karst.). Both stands were affected by bark beetles (in 2003) and subsequent wind-throw resulting in two gaps of $\sim 6,000 \mathrm{~m}^{2}$ (Irschenberg) and 4,000 $\mathrm{m}^{2}$ (Wasserburg). Himalayan balsam was already established at the beginning of the experiment and dominated in both gaps. At Wasserburg only sparse natural regeneration was present. Thus, this site was used for a controlled experiment with artificial regeneration. In agreement with the private woodland owner, we selected Norway spruce and silver fir (Abies alba Mill.) as species which were to be planted. These are the economically most important species in the region. For the plantation, we used standard-sized bare-rooted seedlings from a local nursery (Norway spruce: 2 years old, silver fir: 4 years old). At Irschenberg, abundant natural regeneration dominated by Betula pendula (Roth), a pioneer species of central and northern European forests, was present. Due to the initial conditions with already established but heterogeneously scatted natural regeneration, this site was used for another experiment. This means that no planting was done but the development of the natural regeneration was surveyed at this site. The natural regeneration presumably established itself after the gap accrued, i.e., since 2003 .

The study was carried out using a completely balanced block design. At Wasserburg and Irschenberg, we selected 2 and 3 patches $(\mathrm{O}, \mathrm{P}, \mathrm{A}, \mathrm{B}, \mathrm{C})$. These patches were selected along a Northwest-Southeast transect through the center of the gaps (Fig. 1). At each patch, 4 blocks, each of 


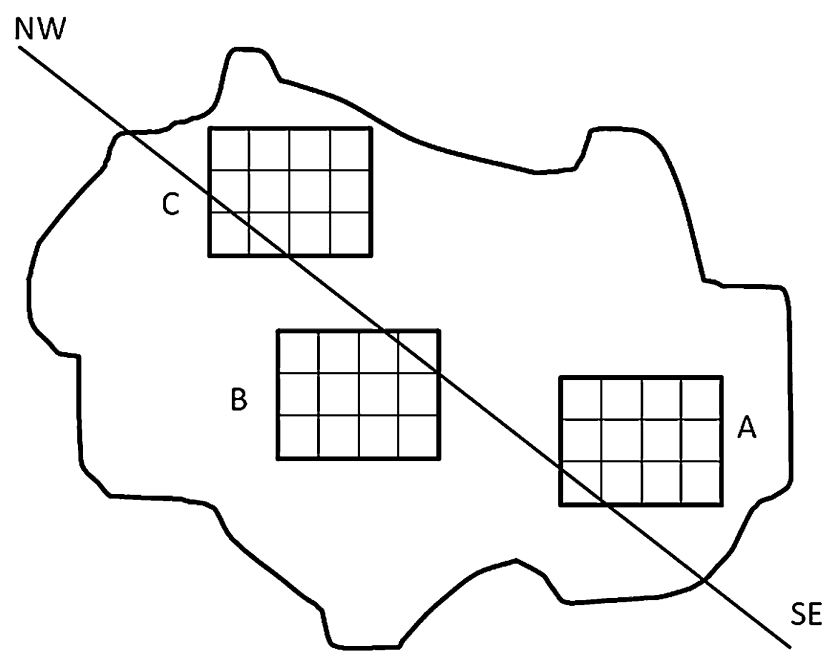

Fig. 1 Experimental design at Irschenberg

which comprised 3 plots, were established (Fig. 1). The size of the plots was $36 \mathrm{~m}^{2}(6 \times 6 \mathrm{~m})$. Three treatments were assigned to these plots: (1) control (without any measures), (2) mowing with a sickle in July before Himalayan balsam releases its seeds, and (3) hand weeding of the entire plant in July. The assignment of the treatments to plots resembled a latin square $(3 \times 3$ plots $)$ plus an additional block with a random placement of the treatments. The latin square part of each block represents a spatially balanced complete block design according van Es et al. (2007).
At Wasserburg, two seedlings per species ( $P$. abies and A. alba) were planted orthogonally at $1.41-\mathrm{m}$ distance from the center of each plot in early Spring 2006. No soil preparation or weed control was conducted while planting. Survival and growth of all planted seedlings was recorded in early spring 2006 and in October 2006, 2007, and 2008. Due to a high browsing pressure by roe deer, both patches were fenced at Wasserburg. For the initial quantities of seedlings height and diameter, see Table 1.

At Irschenberg, data on initial density and size of natural regeneration were recorded in October 2005, 2006, and 2007 (Table 2). Natural regeneration was surveyed within a circular sample unit of $2 \mathrm{~m}$ diameter located in the center of the plot. On these sample units, all (if $N$ per species was $<10$ ) or the 10 tallest individuals (if $N$ per species was $>10$ ) were selected for monitoring. In winter 2006, one block of the patch located at the Northwest edge of the gap was damaged by timber-logging operations. Due to a low browsing pressure, no fencing was carried out at Irschenberg.

Height and diameter ( $3 \mathrm{~cm}$ above ground) were measured for each sampled seedling at both sites at each year in October. Additionally to these measurements, the cover of bramble (Rubus fruticosus) was recorded within a distance of $30 \mathrm{~cm}$ around seedling crown perimeter (visually estimated percent ground cover with a resolution of 5\%). Damages were assessed qualitatively. Since the variables were measured for living individuals only, the cover of bramble is not available for dead trees. Calculated plot

Table 1 Initial quantities and temporal development of seedling number, height, diameter, and cover of bramble within a circle of $30 \mathrm{~cm}$ around a seedling of the experimental site at Wasserburg

\begin{tabular}{|c|c|c|c|c|c|c|c|c|c|c|c|c|c|c|c|}
\hline \multirow[t]{3}{*}{ Time } & \multirow[t]{3}{*}{ Treatment } & \multicolumn{7}{|c|}{ Norway spruce } & \multicolumn{7}{|c|}{ Silver fir } \\
\hline & & \multirow[t]{2}{*}{$N$} & \multicolumn{2}{|c|}{ Height (mm) } & \multicolumn{2}{|c|}{ Diameter $(\mathrm{mm})$} & \multicolumn{2}{|c|}{ Bramble $(\%)$} & \multirow[t]{2}{*}{$N$} & \multicolumn{2}{|c|}{ Height (mm) } & \multicolumn{2}{|c|}{ Diameter (mm) } & \multicolumn{2}{|c|}{ Bramble $(\%)$} \\
\hline & & & Mean & SD & Mean & SD & Mean & SD & & Mean & SD & Mean & SD & Mean & SD \\
\hline \multirow[t]{4}{*}{ Initially (spring 2006) } & & 48 & 421 & 63.3 & 9.3 & 1.83 & & & 48 & 518 & 98.9 & 9.7 & 1.88 & & \\
\hline & Control & 16 & 408 & 60.8 & 10.0 & 2.19 & & & 16 & 513 & 111.3 & 9.5 & 2.38 & & \\
\hline & Mown & 16 & 444 & 63.8 & 9.2 & 1.66 & & & 16 & 509 & 99.2 & 9.6 & 1.64 & & \\
\hline & Hand weeded & 16 & 411 & 62.8 & 8.9 & 1.50 & & & 16 & 532 & 89.9 & 10.1 & 1.59 & & \\
\hline \multirow[t]{4}{*}{ 1st year (autumn 2006) } & & 41 & 509 & 111.6 & 10.3 & 1.97 & 41.7 & 36.5 & 36 & 582 & 99.2 & 11.2 & 2.12 & 45.6 & 34.3 \\
\hline & Control & 11 & 478 & 110.9 & 10.0 & 2.08 & 54.5 & 31.1 & 10 & 539 & 108.8 & 10.6 & 2.19 & 56.0 & 30.3 \\
\hline & Mown & 15 & 523 & 143.7 & 11.0 & 2.31 & 36.0 & 37.9 & 14 & 598 & 92.3 & 11.2 & 1.62 & 31.4 & 32.3 \\
\hline & Hand weeded & 15 & 518 & 71.3 & 9.9 & 1.43 & 38.0 & 38.6 & 12 & 599 & 96.2 & 11.6 & 2.59 & 53.3 & 36.5 \\
\hline \multirow[t]{4}{*}{ 2nd year (autumn 2007) } & & 33 & 610 & 114.1 & 12.4 & 3.36 & 60.0 & 38.3 & 34 & 798 & 180.5 & 13.2 & 2.85 & 59.4 & 36.0 \\
\hline & Control & 8 & 626 & 148.9 & 11.6 & 3.45 & 51.3 & 36.4 & 8 & 744 & 143.6 & 12.2 & 1.74 & 51.3 & 34.0 \\
\hline & Mown & 13 & 621 & 131.1 & 13.3 & 3.70 & 60.8 & 40.3 & 14 & 855 & 188.1 & 13.7 & 2.66 & 49.3 & 39.9 \\
\hline & Hand weeded & 12 & 587 & 64.4 & 12.0 & 2.93 & 65.0 & 39.7 & 12 & 767 & 188.4 & 13.3 & 3.60 & 76.7 & 27.7 \\
\hline \multirow[t]{4}{*}{ 3rd year (autumn 2008) } & & 28 & 842 & 204.7 & 15.3 & 3.85 & 73.6 & 37.8 & 31 & 1,175 & 260.5 & 17.6 & 4.27 & 76.1 & 34.1 \\
\hline & Control & 6 & 819 & 251.6 & 12.6 & 1.58 & 88.3 & 28.6 & 6 & 1,125 & 214.3 & 15.9 & 3.43 & 76.7 & 36.7 \\
\hline & Mown & 13 & 849 & 220.7 & 16.1 & 4.48 & 66.9 & 38.8 & 14 & 1,230 & 247.7 & 18.4 & 4.24 & 63.6 & 35.0 \\
\hline & Hand weeded & 9 & 846 & 168.3 & 15.9 & 3.33 & 73.3 & 42.7 & 11 & 1,132 & 305.0 & 17.5 & 4.78 & 91.8 & 27.1 \\
\hline
\end{tabular}


Table 2 Initial quantities and temporal development of seedling number, height, diameter, and cover of bramble within a circle of $30 \mathrm{~cm}$ around a seedling of the experimental site at Irschenberg (Subset of those plots where 9 or 10 birches or 6-10 spruce seedlings were recorded initially, i.e., 4 plots per treatment)

\begin{tabular}{|c|c|c|c|c|c|c|c|c|c|c|c|c|c|c|c|}
\hline \multirow[t]{3}{*}{ Time } & \multirow[t]{3}{*}{ Treatment } & \multicolumn{7}{|c|}{ Silver birch } & \multicolumn{7}{|c|}{ Norway Spruce } \\
\hline & & \multirow[t]{2}{*}{$N$} & \multicolumn{2}{|c|}{ Height (mm) } & \multicolumn{2}{|c|}{ Diameter $(\mathrm{mm})$} & \multicolumn{2}{|c|}{ Bramble $(\%)$} & \multirow[t]{2}{*}{$N$} & \multicolumn{2}{|c|}{ Height (mm) } & \multicolumn{2}{|c|}{ Diameter $(\mathrm{mm})$} & \multicolumn{2}{|c|}{ Bramble $(\%)$} \\
\hline & & & Mean & SD & Mean & SD & Mean & SD & & Mean & SD & Mean & SD & Mean & SD \\
\hline \multirow[t]{4}{*}{ Initially (spring 2006) } & & 117 & 339 & 160 & 4.3 & 1.9 & 3.2 & 8.1 & 99 & 100 & 33 & 1.8 & 0.6 & 4.7 & 9.7 \\
\hline & Control & 39 & 410 & 169 & 4.9 & 1.7 & 4.2 & 12.1 & 33 & 109 & 32 & 1.9 & 0.6 & 6.1 & 12.4 \\
\hline & Mown & 40 & 324 & 123 & 4.3 & 1.3 & 3.1 & 5.6 & 33 & 81 & 21 & 1.6 & 0.5 & 5.0 & 9.2 \\
\hline & Hand weeded & 38 & 282 & 161 & 3.7 & 2.4 & 2.1 & 4.6 & 33 & 112 & 34 & 2.0 & 0.7 & 3.0 & 6.5 \\
\hline \multirow[t]{4}{*}{ 1st year (autumn 2006) } & & 101 & 916 & 303 & 9.6 & 4.0 & 4.9 & 12.3 & 79 & 207 & 76 & 3.4 & 1.3 & 11.9 & 15.5 \\
\hline & Control & 36 & 978 & 289 & 10.1 & 4.3 & 8.2 & 18.9 & 29 & 216 & 52 & 3.6 & 1.3 & 8.3 & 16.7 \\
\hline & Mown & 37 & 884 & 288 & 8.6 & 2.9 & 2.3 & 5.5 & 25 & 156 & 35 & 3.0 & 1.0 & 12.5 & 16.5 \\
\hline & Hand weeded & 28 & 877 & 336 & 10.4 & 4.7 & 3.9 & 5.5 & 25 & 246 & 99 & 3.5 & 1.5 & 15.6 & 12.6 \\
\hline \multirow[t]{4}{*}{ 2nd year (autumn 2007) } & & 89 & 1,721 & 342 & 15.9 & 7.1 & 8.1 & 17.2 & 61 & 317 & 100 & 4.9 & 1.5 & 15.0 & 17.7 \\
\hline & Control & 34 & 1,766 & 344 & 16.6 & 6.5 & 12.9 & 25.8 & 23 & 353 & 75 & 5.3 & 1.3 & 3.0 & 7.6 \\
\hline & Mown & 33 & 1,662 & 311 & 13.5 & 5.2 & 3.9 & 7.5 & 22 & 262 & 92 & 4.6 & 1.4 & 20.0 & 22.3 \\
\hline & Hand weeded & 22 & 1,740 & 385 & 18.5 & 9.4 & 6.8 & 7.2 & 16 & 340 & 116 & 4.6 & 1.9 & 22.9 & 13.5 \\
\hline
\end{tabular}

means of bramble cover are therefore related to living trees.

Statistical analysis was done using $\mathrm{R}$ Version 2.8.1 (R Development Core Team 2008). We analyzed seedling survival at plot and individual tree level. Height and diameter growth were analyzed for individual seedlings. Mixed models were used with random effects due to spatial nesting and temporal pseudoreplication (if several years were analyzed). Random effects at the plot level are due from patches and blocks. At the individual tree level, we additionally specified random effects for plots. The values of bramble cover were arcsine square-root transformed.

The percentage of surviving seedlings on the plot level was analyzed using logistic regression for the Wasserburg site. The main explanatory variable was treatment. By including tree species into the model, we tested for differences in survival between Norway spruce and silver fir. The temporal development of survival was analyzed by introducing time as additional explanatory variable. The survival of individual seedlings was conducted as binary logistic analysis with treatment and coverage of bramble in the preceding year as explanatory variables. For both analyses, i.e., on the plot level and on individual seedling level, a general linear mixed effects model (glmer of R-package lme4) was used and fit by the Laplace approximation.

Multiple linear mixed effects regression models were used to analyze the annual height and diameter growth on the individual tree level (function lme of R-package nlme). Coverage of bramble, and both, height and diameter at the beginning of the vegetation period were tested as explanatory variables. In order to allow for model comparisons (function anova of R-package stats), the models were fit by the maximum likelihood method. Subsequently, the final model was fit by the restricted maximum likelihood (REML) approach.

At the Irschenberg site, only Picea abies $(N=130)$ and Betula pendula $(N=152)$ were found in high numbers. Besides these two species Abies alba $(N=50)$ and seven other species with less than 20 seedlings were recorded. Thus, only the data of birch (Betula spec.) and spruce (Picea abies) were evaluated. The abundance of birch was found to be uneven between patches and plots: No birches were recorded on 12 plots, 9 plots showed only 1-3 seedlings and only on 15 plots $>4$ seedlings could be found. These plots only belonged to the patches A and B. For data evaluation, we selected those plots with more than 8 birches $(N=12)$. Numerically, these plots were evenly distributed over treatments (4 plots per treatment) and patches (6 plots per patch $\mathrm{A}$ and $\mathrm{B}$ ). However, the treatments mowing and hand weeding were unbalanced between the patches ( 3 plots at patch $\mathrm{A}$ and 1 at patch $\mathrm{B}$ for treatment mowing and inversely for treatment hand weeding). Spruce was more evenly distributed on the three patches than birch. However, no spruce seedlings could be found on 13 plots $(5,3$, and 5 for patches $A, B$, and $C$, respectively), and 1-3 seedlings were recorded on 7 plots (3, 3, and 1 for patches A, B, and C, respectively). For data evaluation, we selected plots with more than 5 spruce seedlings $(N=12)$. These plots were evenly distributed over treatments $(N=4)$, but unevenly over patches $(2,4$, and 6 for patches $\mathrm{A}, \mathrm{B}$, and $\mathrm{C}$, respectively). For the statistical analyses, we treated the selected plots as randomly selected samples, since the actual seedling presence and 
abundance was not predetermined or controlled by the design of the experiment. Hence, we analyzed seedling's survival at plot level using logistic regression without random effects (function glm) whereas individual seedling growth was analyzed using multiple linear regression with random effects between plots. The plot mean of bramble cover was used as an explanatory variable for analyzing the effect of bramble cover on mortality of birch and spruce on the plot level.

We used the model simplification method (Crawley 2007) to determine the minimal adequate model for analyses comprising either more than one explanatory variable or categorical explanatory variables with more than two levels. Homogeneity of the initial conditions with respect to seedling height and diameter in both experiments was tested using ANOVA.

\section{Results}

Mortality of planted spruce and fir seedlings was observed for all treatments and both species (Table 1) at the Wasserburg site. On the plot level, no species effect on mortality, measured as proportion of living seedlings relative to the initial seedling number, could be detected at the end of the experiment in 2008. However, the survival of both species pooled together did significantly depend on the treatment. The survival rate was lowest for the control, significantly higher for the treatment hand weeding, and significantly highest for mowing (Table 3 ). This finding was supported by analyzing seedling survival over the whole period (2006-2008) on plot level. In addition to the treatments, time was identified as a significant factor (Table 4), indicating increasing mortality over time.

Analyses of intra-year tree mortality (2006-2007 and 2007-2008) on the individual tree level did not show an impact of previous year coverage of bramble on seedling mortality. However, the analyses were restricted due to the

Table 3 Survival of seedlings (spruce and fir pooled) at the Wasserburg site for the year 2008

\begin{tabular}{lrllrl}
\hline & Estimate & SE & $d f^{\mathrm{a}}$ & $z$ value & $\operatorname{Pr}(>|z|)$ \\
\hline (Intercept) & -0.525 & 0.385 & 14 & -1.363 & 0.1728 \\
Treatment: mown & 2.249 & 0.614 & 14 & 3.662 & 0.0003 \\
Treatment: hand weeded & 1.049 & 0.519 & 14 & 2.023 & 0.0430
\end{tabular}

Logistic regression (general linear mixed effects model) with random effects accounting for spatial nesting of plots $(N=24)$. Units expressed in logits. Model and differences between treatments are significant at the $5 \%$ error level

${ }^{\text {a }} d f$ estimated by a linear mixed effects model (lme of R-package nlme) with identical formulation of fixed and random effects, but using the counts of surviving seedlings as response variable instead of the proportion
Table 4 Survival of seedlings (spruce and fir pooled) at the Wasserburg site for the 3-year period (2006-2008)

\begin{tabular}{lrlllr}
\hline & Estimate & SE & $d f^{1}$ & $z$ value & $\operatorname{Pr}(>|z|)$ \\
\hline (Intercept) & 1.097 & 0.425 & 61 & 2.582 & 0.0098 \\
Treatment: mown & 1.922 & 0.373 & 61 & 5.154 & $<0.0001$ \\
$\begin{array}{l}\text { Treatment: hand } \\
\quad \text { weeded }\end{array}$ & 1.072 & 0.319 & 61 & 3.359 & 0.0008 \\
$\quad$ Year & -0.527 & 0.176 & 61 & -3.002 & 0.0027
\end{tabular}

Logistic regression (general linear mixed effects model) with random effects accounting for temporal pseudoreplication and spatial nesting of plots $(N=72)$. Units expressed in logits; years counted from the beginning of the experiment, i.e., 2006 equals year 1. Model and differences between treatments are significant at the 5\% error level

${ }^{a} d f$ estimated by a linear mixed effects model (lme of R-package nlme) with identical formulation of fixed and random effects, but using counts of surviving seedlings as response variable instead of the proportion

low absolute number of seedlings dying from year to year and the high and homogeneous cover of bramble toward the end of the survey. Mean cover of bramble in 2006 was above $40 \%$ for both spruce and fir and increased continuously (Table 1). Differences between patches (2006: O: 29.0\%, P: $60.0 \%$ ) decreased over time (2008; O: $72.7 \%$, P: $86.5 \%)$. Variance component analysis revealed that $19.6 \%$ of the overall variance of bramble cover (transformed values) originated from patches in 2006. This value decreased to $10.0 \%$ in 2007 and dropped close to zero in 2008. Variance components of both, treatment and blocks were close to zero $\left(<10^{-9} \%\right)$ for all years.

Mean seedling height in autumn 2008 was comparable between the treatments for both species (Table 1). However, mean seedling diameter of the control was lower for fir and significantly lower for spruce $(N=28, P=0.0092$ for simple ANOVA and $P=0.0182$ for linear mixed effect model) compared to both weed control treatments. Individual tree growth of spruce and fir trees at Wasserburg was affected by treatments and bramble cover (Tables 5 and 6), and there were differences between years. Height growth of fir seedlings was nearly doubled by mowing and hand weeding in 2006 compared to the control. In 2007, no treatment effect was found but the cover of bramble negatively affected height growth. In 2008, initial height at the beginning of the vegetation period was the only variable determining current year height growth. Diameter growth of fir seedlings was positively influenced by mowing and hand weeding and negatively affected by bramble only in 2007. In 2008 , initial height at the beginning of the vegetation period was found to significantly influence diameter growth (Table 5). In contrast to fir, height growth of Norway spruce seedlings could not be explained by the variables tested in 2006 and 2007 (Table 6). In 2008, however, the diameter at the beginning of the vegetation period was found to 
Table 5 Results of the regression analyses of silver fir seedlings height and diameter increment at Wasserburg (linear mixed effects model with random effects accounting for spatial nesting of plots)

\begin{tabular}{|c|c|c|c|c|c|c|c|c|}
\hline \multirow[t]{2}{*}{ Variable } & \multirow[t]{2}{*}{ Year } & \multirow[t]{2}{*}{$N$} & \multirow[t]{2}{*}{ Model } & \multicolumn{5}{|l|}{ Coefficients } \\
\hline & & & & Estimate & SE & $d f$ & $t$-value & $P$ value \\
\hline \multirow[t]{6}{*}{ Height increment } & \multirow[t]{2}{*}{2006} & \multirow[t]{2}{*}{34} & (Intercept) & 43.44 & 17.52 & 14 & 2.4795 & 0.0265 \\
\hline & & & $\operatorname{IgR}$ & 44.99 & 20.96 & 14 & 2.1465 & 0.0498 \\
\hline & \multirow[t]{2}{*}{2007} & \multirow[t]{2}{*}{31} & (Intercept) & 331.1 & 38.2 & 13 & 8.6664 & $<0.0001$ \\
\hline & & & $\mathrm{CO}$ & -105.1 & 34.8 & 9 & -3.0214 & 0.0144 \\
\hline & \multirow[t]{2}{*}{2008} & \multirow[t]{2}{*}{30} & (Intercept) & -7.924 & 120.8 & 13 & -0.0656 & 0.9487 \\
\hline & & & $H$ & 0.426 & 0.142 & 8 & 3.0116 & 0.0168 \\
\hline \multirow[t]{6}{*}{ Diameter increment } & 2006 & 34 & NS & & & & & \\
\hline & \multirow[t]{3}{*}{2007} & \multirow[t]{3}{*}{33} & (Intercept) & 3.21 & 0.87 & 13 & 3.7006 & 0.0027 \\
\hline & & & $\mathrm{CO}$ & -2.40 & 0.51 & 10 & -4.7174 & 0.0008 \\
\hline & & & $\operatorname{IgR}$ & 1.37 & 0.52 & 13 & 2.6551 & 0.0198 \\
\hline & \multirow[t]{2}{*}{2008} & \multirow[t]{2}{*}{30} & (Intercept) & -1.64 & 1.59 & 13 & -1.0347 & 0.3197 \\
\hline & & & $H$ & 0.0069 & 0.0016 & 8 & 4.2248 & 0.0029 \\
\hline
\end{tabular}

CO labels cover of bramble in the corresponding year; $\operatorname{IgR}$ labels mowing and hand weeding; $H$ is the initial height at the beginning of the vegetation period. Models are significant at the 5\% error level

significantly impact height growth. For the diameter growth of spruce, treatment effects were found in 2007, and an impact of bramble was revealed in 2007 and 2008 (Table 6).

At the Irschenberg site, the seedling number of birch on the control plots decreased slightly to $92 \%$ (2006) and $87 \%$ (2007) of the initial value (Table 2). A comparable decrease was found for the mowing treatment (to $92 \%$ in 2006 and 82\% in 2007). On the hand-weeded plots, however, the number of seedlings was reduced to $74 \%$ of the initial value in 2006 and to 58\% in 2007 (Table 2), but this reduction was not statistically significant for both years when analyzed at plot level. In addition, no significant impact of bramble on survival was found. At the beginning of the experiment mean cover of bramble at Irschenberg was low for patches and treatments (Table 7). The development of bramble coverage in the following years was different between the patches, showing a high increase at patch $\mathrm{C}$, a medium increase at patch $\mathrm{B}$ and a small increase at patch A (Table 7). The variance component of bramble cover for the patches increased from close to zero in spring 2006 to $38.3 \%$ in 2007. Concerning the treatments, the mean cover increased for all treatments but showed high variability due to the effect of patches and the variability between plots. For the treatments the variance component was close to zero for all years.

Table 6 Results of the regression analyses of Norway spruce seedlings height and diameter increment at Wasserburg (linear mixed effects model with random effects accounting for spatial nesting of plots)

\begin{tabular}{|c|c|c|c|c|c|c|c|c|}
\hline \multirow[t]{2}{*}{ Variable } & \multirow[t]{2}{*}{ Year } & \multirow[t]{2}{*}{$N$} & \multirow[t]{2}{*}{ Model } & \multicolumn{5}{|c|}{ Coefficients } \\
\hline & & & & Estimate & SE & $d f$ & $t$-value & $P$ value \\
\hline \multirow[t]{4}{*}{ Height increment } & 2006 & 38 & & NS & & & & \\
\hline & 2007 & 30 & & NS & & & & \\
\hline & 2008 & 26 & (Intercept) & -115.0 & 77.6 & 9 & -1.4825 & 0.1723 \\
\hline & & & $D$ & 25.4 & 5.1 & 8 & 4.9606 & 0.0011 \\
\hline \multirow[t]{6}{*}{ Diameter increment } & 2006 & 36 & & NS & & & & \\
\hline & 2007 & 28 & (Intercept) & 1.85 & 0.76 & 10 & 2.4385 & 0.0349 \\
\hline & & & $\operatorname{Ig} R$ & 2.43 & 0.75 & 10 & 3.2247 & 0.0091 \\
\hline & & & $\mathrm{CO}$ & -1.45 & 0.60 & 8 & -2.3920 & 0.0437 \\
\hline & 2008 & 25 & (Intercept) & 4.63 & 0.58 & 8 & 8.0452 & $<0.0001$ \\
\hline & & & $\mathrm{CO}$ & -1.67 & 0.46 & 8 & -3.6619 & 0.0064 \\
\hline
\end{tabular}

CO labels cover with bramble in the corresponding year; IgR labels mowing and hand weeding; $D$ is the initial diameter at the beginning of the vegetation period. Models are significant at the $5 \%$ error level 
Table 7 Development of bramble ground cover (in \%) at Irschenberg
Values are based on plot means for all plots comprising more than two individual trees irrespective of tree species

\begin{tabular}{|c|c|c|c|c|c|c|c|c|c|c|}
\hline \multirow[t]{2}{*}{ Place } & \multirow[t]{2}{*}{ Treatment } & \multicolumn{3}{|c|}{2005} & \multicolumn{3}{|c|}{2006} & \multicolumn{3}{|c|}{2007} \\
\hline & & $N$ & Mean & SD & $N$ & Mean & SD & $N$ & Mean & SD \\
\hline \multirow[t]{4}{*}{$A$} & & 3 & 2.5 & 2.4 & 3 & 3.8 & 3.8 & 3 & 4.9 & 5.9 \\
\hline & Control & 3 & 0.1 & 0.1 & 3 & 0.0 & 0.0 & 3 & 0.0 & 0.0 \\
\hline & Mowing & 3 & 4.8 & 3.3 & 3 & 3.8 & 3.3 & 3 & 3.3 & 3.3 \\
\hline & Hand weeded & 3 & 2.8 & 2.6 & 3 & 7.6 & 7.1 & 2 & 11.4 & 12.2 \\
\hline \multirow[t]{4}{*}{$B$} & & 3 & 2.5 & 1.7 & 3 & 8.2 & 3.1 & 3 & 20.4 & 11.8 \\
\hline & Control & 4 & 4.0 & 7.9 & 4 & 11.6 & 20.5 & 3 & 33.9 & 37.0 \\
\hline & Mowing & 3 & 0.6 & 1.0 & 3 & 7.5 & 7.7 & 3 & 14.7 & 11.2 \\
\hline & Hand weeded & 3 & 2.8 & 4.7 & 3 & 5.4 & 4.2 & 3 & 12.5 & 4.3 \\
\hline \multirow[t]{4}{*}{$C$} & & 3 & 6.0 & 5.0 & 3 & 26.9 & 12.7 & 3 & 41.9 & 9.3 \\
\hline & Control & 4 & 9.7 & 12.7 & 4 & 37.8 & 27.3 & 3 & 48.1 & 45.3 \\
\hline & Mowing & 2 & 7.9 & 11.2 & 1 & 30.0 & - & 1 & 46.3 & - \\
\hline & Hand weeded & 3 & 0.4 & 0.6 & 3 & 13.0 & 11.3 & 2 & 31.2 & 3.1 \\
\hline \multirow[t]{4}{*}{$A+B+C$} & & 9 & 3.7 & 3.4 & 9 & 13.0 & 12.6 & 9 & 22.4 & 18.0 \\
\hline & Control & 3 & 4.6 & 4.9 & 3 & 16.4 & 19.4 & 3 & 27.3 & 24.7 \\
\hline & Mowing & 3 & 4.4 & 3.7 & 3 & 13.8 & 14.2 & 3 & 21.4 & 22.2 \\
\hline & Hand weeded & 3 & 2.0 & 1.4 & 3 & 8.7 & 3.9 & 3 & 18.4 & 11.1 \\
\hline
\end{tabular}

The development of spruce seedlings number was comparable to that of birch. Thus, for the control and the mowing treatment, the decrease in seedling density was lower (control: to $88 \%$ of the initial value in 2006 and to $70 \%$ in 2007 , mowing: to $78 \%$ in 2006 and to $67 \%$ in 2007) than for hand weeding (decrease to $78 \%$ in 2006 and to $48 \%$ in 2007; Table 2). As for birch, the treatment effect was not statistically significant when analyzed at plot level. However, spruce seedling survival was negatively influenced by the cover of bramble if one outlier plot (a mowing treatment at place $\mathrm{C}$ ) was removed from the data set. This resulted in a significant negative relationship between the percentage of surviving seedlings in 2007 (relative to the initial seedling number) and bramble cover for the same year $(P=0.0235)$. For year
2006, this relationship was close to being significant $(P=0.068)$.

On the individual seedling level, a treatment effect on diameter growth of birch seedlings (interaction with initial diameter) was found in 2006 (Table 8). No such relationship could be found for diameter growth in 2007 and height growth in both years. Seedling growth only depended on initial size (diameter).

Neither treatment nor competition by bramble affected diameter and height growth of spruce seedlings (Table 9). Diameter growth in 2006 and height growth in 2006 and 2007 only depended on initial size at the beginning of the regarding vegetation period (Table 9). For both variables, initial diameter could explain more of the variation in the data set than initial height.

Table 8 Results of the regression analyses of Silver birch seedlings height and diameter growth at Irschenberg (linear mixed effects model with random effects on the plot level)

\begin{tabular}{|c|c|c|c|c|c|c|c|c|}
\hline \multirow[t]{2}{*}{ Variable } & \multirow[t]{2}{*}{ Year } & \multirow[t]{2}{*}{$N$} & \multirow[t]{2}{*}{ Model } & \multicolumn{5}{|c|}{ Coefficients } \\
\hline & & & & Estimate & SE & $d f$ & t-value & $P$ value \\
\hline \multirow[t]{3}{*}{ Height increment } & 2006 & 96 & (Intercept) & 231.1 & 61.6 & 83 & 3.7494 & 0.0003 \\
\hline & & & $D$ & 69.5 & 11.5 & 83 & 6.0466 & $<0.0001$ \\
\hline & 2007 & 89 & \multicolumn{6}{|c|}{ Not applicable because 43 trees exceeded measurement cap of 2 meters } \\
\hline \multirow[t]{5}{*}{ Diameter increment } & 2006 & 94 & (Intercept) & 1.15 & 0.71 & 80 & 1.6276 & 0.1075 \\
\hline & & & $D$ & 0.63 & 0.14 & 80 & 4.5011 & $<0.0001$ \\
\hline & & & $D: \operatorname{IgR}$ & 0.39 & 0.16 & 80 & 2.4138 & 0.0181 \\
\hline & 2007 & 85 & (Intercept) & -0.75 & 0.71 & 72 & -1.0611 & 0.2922 \\
\hline & & & $D$ & 0.69 & 0.07 & 72 & 9.5024 & $<0.0001$ \\
\hline
\end{tabular}

IgR labels mowing and hand weeding; $D$ is the initial diameter at the beginning of the vegetation period. Models are significant at the 5\% error level 
Table 9 Results of the regression analyses of Norway spruce seedlings height and diameter growth at Irschenberg (linear mixed effects model with random effects on the plot level)

\begin{tabular}{|c|c|c|c|c|c|c|c|c|}
\hline \multirow[t]{2}{*}{ Variable } & \multirow[t]{2}{*}{ Year } & \multirow[t]{2}{*}{$N$} & \multirow[t]{2}{*}{ Model } & \multicolumn{5}{|c|}{ Coefficients } \\
\hline & & & & Estimate & SE & $d f$ & $t$-value & $P$ value \\
\hline \multirow[t]{4}{*}{ Height increment } & \multirow[t]{2}{*}{2006} & \multirow[t]{2}{*}{74} & (Intercept) & 38.0 & 18.8 & 62 & 2.0200 & 0.0477 \\
\hline & & & $D$ & 32.6 & 9.6 & 62 & 3.3964 & 0.0012 \\
\hline & \multirow[t]{2}{*}{2007} & \multirow[t]{2}{*}{54} & (Intercept) & 67.6 & 23.3 & 43 & 2.9036 & 0.0058 \\
\hline & & & $D$ & 16.1 & 5.9 & 43 & 2.7162 & 0.0095 \\
\hline \multirow[t]{3}{*}{ Diameter increment } & \multirow[t]{2}{*}{2006} & \multirow[t]{2}{*}{77} & (Intercept) & 0.69 & 0.40 & 65 & 1.7474 & 0.0853 \\
\hline & & & $D$ & 0.41 & 0.19 & 65 & 2.1747 & 0.0333 \\
\hline & 2007 & 52 & & NS & & & & \\
\hline
\end{tabular}

$D$ is the initial diameter at the beginning of the vegetation period. Models are significant at the $5 \%$ error level

\section{Discussion}

At both sites, the results of our experiment did not support the hypothesis that Impatiens glandulifera is a strong competitor of already established tree seedlings. For all species height and diameter growth were only occasionally positively influenced by any of the two different weeding techniques (Tables 5, 6, 8, 9). In contrast to growth, treatment effects on seedling survival could be found for planted Norway spruce and silver fir. However, a closer look at the results at the Wasserburg site suggests that these effects, i.e., higher seedling survival after mowing, have to be attributed to the control of bramble (Rubus fruticosus) rather than to that of Himalayan balsam (Tables 1, 5, 6). In fact, mowing resulted in statistically highly significant survival rates of spruce and fir seedlings until 2008. In contrast to hand weeding, which removed only Himalayan balsam, mowing did affect not only Himalayan balsam but also all other weeds. Consequently, the mean cover of bramble on these plots was lower than that of the two other treatments, in two out of 3 years (Table 1). Moreover, bramble was found to negatively impact tree seedling diameter growth more often than Himalayan balsam (Tables 5 and 6). In 2008, initial seedling size at the beginning of the vegetation period was the only variable determining current year height growth of fir and spruce at the Wasserburg site. This result suggests that the planted seedlings have already passed the (weak) competition effect on height growth of Impatiens glandulifera and bramble (Tables 5 and 6). In contrast to height growth, diameter growth of Norway spruce was affected by bramble even in 2008 (Table 6). It is known from many other studies that height growth response of tree seedlings and saplings to competition is less pronounced than that of stem diameter (Wagner and Röker 2000; Duchesneau et al. 2001; Ammer et al. 2005). In conclusion, it is very likely that the treatment effects that are rare anyhow have to be attributed to bramble and not to Himalayan balsam. This assumption is supported by the reports in literature about the differing impacts of the two species on other plants. Whereas several studies illustrate the negative impact of Rubus fruticosus on tree seedlings establishment and growth (e. g. Fotelli et al. 2001; Fotelli et al. 2005; Harmer et al. 2005), no comparable information exists for Himalayan balsam. To our knowledge, there is no evidence that this species is able to outcompete already established tree seedlings or even substantially reduce their growth so far.

Much more information is available on detrimental effects by Himalayan balsam on herbaceous native species. However, even for herbaceous species, contradicting results have been reported. Whereas some studies have classified Impatiens glandulifera as a strong competitor to native herbaceous species by shading them out and thus leading to a reduction of species richness (Manchester and Bullock 2000; Hulme and Bremner 2006), others observed a very little effect on community characteristics (Hejda and Pyšek 2006; Hejda et al. 2009; Bartomeus et al. 2010). These different assessments may be attributed to differences in the cover of Himalayan balsam (Hejda and Pyšek 2006). This means that in areas like ours where the cover with Impatiens glandulifera is not spatially homogeneous (which is very often the case in forests), not much consideration has to be given to the detrimental effects of that alien on species diversity (Hejda and Pyšek 2006). Insofar, the situation in our stands represented typical conditions. In our experiment, the estimated, though not systematically assessed, cover of Himalayan balsam was very likely to be considerably below $80 \%$. We therefore cannot answer the question whether the very weak impact of Himalayan balsam on seedling growth and survival was due to a too low cover or caused by the robustness of birch, Norway spruce and silver fir against Impatiens glandulifera. Even though our study was completed in only a few years, it is very likely that Himalayan balsam is not able to seriously affect the growth of already established seedlings. In the few cases where a statistically significant positive impact 
of the reduction of Himalayan balsam was detected it did not occur in the last years of the observation period. This means that if there had been a negative effect of Himalayan balsam on newly emerged seedlings, this effect was vanishing over time. Also this species does not seem to change soil characteristics (Hejda and Pyšek 2006) and is not able to occupy belowground soil compartments by rhizomes (Hejda et al. 2009). Finally, the species is highly sensitive to drought and frost, resulting in periods of less thickness and hence reduced competition for light and belowground resources (Beerling and Perrins 1993). Nevertheless, there might be a detrimental effect of Himalayan Balsam on tree recruitment, which is yet to be tested. In summary, our experiment therefore supports the conclusion of Hejda and Pyšek (2006) that the impact of Impatiens glandulifera is considerably less dramatic than that of other invasive species. At some sites, where it does not dominate, it may complete a not fully occupied ecological niche (Kowarik 2003). In fact, Vor and Schmidt (2008) found that Impatiens glandulifera had established an additional herbaceous layer without eliminating other species in a riparian forest in Germany (near Hördt/Rhineland-Palatinate).

As the complete eradication of Himalayan balsam is unrealistic, as it would cause high expenses and would require coordinated actions on regional or national scale over a long period (Wadsworth et al. 2000), maintenance control seems to be a more promising option (Mack et al. 2000). According to Hejda and Pyšek (2006), management decisions should be based on the assessment on the invasive species' dominance compared to that of the native species. However, from a silvicultural viewpoint such measures will only be needed occasionally. As chemical control is discredited throughout Europe (see Willoughby et al. 2009) and the control of Himalayan balsam by antagonists in its invaded range has failed until today (Burkhart and Nentwig 2008), mechanical methods are the remaining option. Although pulling out the stems of Himalayan balsam is easily performed this method is time consuming and, as in our experiment, not very effective. This method may also result in a loss of seedlings, which was obviously the case for birch (Table 2). Furthermore, this method is not suitable in situations where Himalayan balsam is not the only weed. Therefore, mowing or trembling around the seedlings seems to be the more effective management options. Even though such measures are of short-term efficiency they can provide a head-start for tree seedlings and/or restrict the occurrence of the invasive species which may lead to a higher diversity of native species (Hulme and Bremner 2006).

Acknowledgments We are grateful to J. Waldschütz and G. Glas who gave us access to their woodlands. We also thank two anonymous reviewers for helpful comments and Peter Annighöfer for linguistic corrections.
Open Access This article is distributed under the terms of the Creative Commons Attribution Noncommercial License which permits any noncommercial use, distribution, and reproduction in any medium, provided the original author(s) and source are credited.

\section{References}

Ammer C, Ziegler C, Knoke T (2005) Zur Beurteilung von intraund interspezifischer Konkurrenz von Laubbaumbeständen im Dickungsstadium. Allgemeine Forst- und Jagdzeitung 176: 85-94

Ammer C, Blaschke M, Muck P (2009) Germany. In: Willoughby I, Balandier P, Bentsen NS, McCarthy N, Claridge J (eds) Forest vegetation management in Europe: current practice and future requirements. COST Office, Brussels, pp 43-50

Andrews M, Hamish GM, Hodge S, Cherrill A, Raven JA (2009) Seed dormancy, nitrogen nutrition and shade acclimation of Impatiens glandulifera: implications for successful invasion of deciduous woodland. Plant Ecol Divers 2:145-153

Bartomeus I, Vilà M, Steffan-Dewenter I (2010) Combined effects of Impatiens glandulifera invasion and landscape structure on native plant pollination. J Ecol 98:440-450

Beerling D, Perrins J (1993) Impatiens glandulifera Royle (Impatiens roylei Walp.). J Ecol 81:367-382

Burkhart K, Nentwig W (2008) Control of Impatiens glandulifera (Balsaminaceae) by antagonists in its invaded range. Invasive Plant Science and Management 1:352-358

Crawley MJ (2007) The R book. Wiley, Chichester

Dierschke H (2008) Dynamik und Konstanz an naturnahen Flussufern-27 Jahre Daueruntersuchungen am Oderufer (Harzvorland). Braunschweiger Geobotanische Arbeiten 8:119-138

Duchesneau R, Lesage I, Messier C, Morin H (2001) Effects of light and intraspecific competition on growth and crown morphology of two size classes of understory balsam fir saplings. For Ecol Manage 140:215-225

Fotelli MN, Geßler A, Peuke AD, Rennenberg H (2001) Drought affects the competitive interactions between Fagus sylvatica seedlings and an early successional species, Rubus fruticosos: responses of growth, water status and $\delta^{13} \mathrm{C}$ composition. New Phytol 151:427-435

Fotelli MN, Rudolph P, Rennenberg H, Geßler A (2005) Irradiance and temperature affect the competitive interference of blackberry on the physiology of European beech seedlings. New Phytol 165:453-462

Grime J, Hodgson J, Hunt R, Band S, Claphan A (1988) Comparative plant ecology: a functional approach to common British Species. Unwin Hyman, London

Grime J, Hodgson J, Hunt R (2007) Comparative plant ecology: a functional approach to common British species. Castlepoint Press, Colvend

Harmer R, Boswell R, Robertson M (2005) Survival and growth of tree seedlings in relation to changes in the ground flora during natural regeneration of an oak shelterwood. Forestry 78:21-32

Hartmann E, Schuldes H, Kübler R, Konold W (1995) Neophyten: Biologie, Verbreitung und Kontrolle ausgewählter Arten. Landsberg am Lech, Ecomed

Hejda M, Pyšek P (2006) What is the impact of Impatiens glandulifera on species diversity of invaded riparian vegetation. Biol Conserv 132:143-152

Hejda M, Pyšek P, Jarošik V (2009) Impact of invasive plants on the species richness, diversity and composition of invaded communities. J Ecol 97:393-403 
Hulme PE, Bremner ET (2006) Assessing the impact of Impatiens glandulifera on riparian habitats: partitioning diversity components following species removal. J Appl Ecol 43:43-50

Koenies H, Glavac V (1979) The ability of Impatiens glandulifera to compete on the banks of the River Fulda near Kassel, West Germany. Philippia 4:47-49

Kowarik I (2003) Biologische Invasionen: Neophyten und Neozoen in Mitteleuropa. Ulmer, Stuttgart

Lohmeyer W, Sukopp H (1992) Agriophyten in der Vegetation Mitteleuropas. Bundesforschungsanstalt für Naturschutz und Landschaftsökologie, Bonn. 185 pp

Ludwig M, Gebhardt H, Ludwig H, Schmidt-Fischer S (2000) Neue Tiere \& Pflanzen in der heimischen Natur. BLV Verlagsgesellschaft, München

Mack RN, Simberloff D, Londsdale WM, Evans H, Clout M, Bazzaz FA (2000) Biotic invasions: causes, epidemiology, global consequences, and contrl. Ecol Appl 10:689-710

Manchester SJ, Bullock JM (2000) The impact of non-native species on UK biodiversity and the effectiveness of control. J Appl Ecol 37:845-864

Prowse AJ, Goodridge F (2003) Experimental invasion of woodland by the alien Impatiens glandulifera: the role of slug herbivory. In: Child LE, Brock JH, Brundu G, Prach K, Pyšek P, Wade PM, Williamson $M$ (eds) Plant invasions: ecological threats and management solutions. Netherlands Backhuys, Leiden, pp 301-311
Pyšek P, Prach K (1995) Invasion dynamics of Impatiens glandulifera-A century of spreading reconstructed. Biol Conserv 74:41-48

R Development Core Team (2008) R: a language and environment for statistical computing. R Foundation for Statistical Computing, Vienna, Austria

Richardson DM, Pyšek P, Rejmánek M, Barbour MG, Panetta FD, West CJ (2000) Naturalization and invasion of alien plants: concepts and definitions. Divers Distrib 6:93-107

Toney J, Rice P, Forecella F (1998) Exotic plant records in the northwest United States 1950-1996: an ecological assessment. Northwest Sci 72:198-213

van Es HM, Gomes CP, Sellmann M, van Es CL (2007) Spatiallybalanced complete block designs for field experiments. Geoderma 140:346-352

Vor T, Schmidt W (2008) Neophyten in der Hördter Rheinaue/ Rheinland Pfalz. Forstarchiv 79:143-151

Wadsworth RA, Collingham YC, Willis SG, Huntley B, Hulme PE (2000) Simulating the spread and management of alien riparian weeds: are they out of control? J Appl Ecol 37(Suppl. 1):28-38

Wagner S, Röker B (2000) Birkenanflug in StieleichenkulturenUntersuchungen zur Dynamik der Konkurrenz über 5 Vegetationsperioden. Forst und Holz 55:18-22

Willoughby I, Balandier P, Bentsen NS, McCarthy N, Claridge J (eds) (2009) Forest vegetation management in Europe: current practice and future requirements. COST Office, Brussels 